\title{
Panophthalmitis in a Gentoo Penguin (Pygoscelis Papua) From The Antarctic Peninsula: Evaluation of Microbiological and Histopathological Analysis Outcomes
}

\section{Latife CAKIR BAYRAM ( $\sim$ lcakir@erciyes.edu.tr)}

Erciyes Üniversitesi: Erciyes Universitesi https://orcid.org/0000-0002-3029-1000

\section{Seçil ABAY}

Erciyes University: Erciyes Universitesi

Izzet Burçin SATICIOĞLU

Erciyes University

\section{Tolga GÜVENÇ}

Ondokuz Mayis University: Ondokuz Mayis Universitesi

\section{Görkem EKEBAŞ}

Erciyes University: Erciyes Universitesi

\section{Fuat AYDIN}

Erciyes University: Erciyes Universitesi

\section{Research Article}

Keywords: Gentoo penguin (Pygoscelis papua), ocular exfoliative cytology, panophthalmitis, putative novel bacteria, inflammatory mediators, immunohistochemistry

Posted Date: February 15th, 2021

DOl: https://doi.org/10.21203/rs.3.rs-190292/v1

License: (1) (i) This work is licensed under a Creative Commons Attribution 4.0 International License. Read Full License 


\section{Abstract}

In this study, it was aimed to present the results of microbiological, cytological, histopathological, and immunohistochemical analyses of ocular samples from an Antarctic (Ardley Island, King George Island) Gentoo penguin chick (Pygoscelis papua) with pyogranulomatous panophthalmitis in the right eye. Samples were taken from both the healthy left eye and the lesion in the right eye. Conventional culture methods and phenotypic and molecular tests were used for bacterial isolation and identification, respectively. None of the isolates could be identified phenotypically. As a result, four of the five isolates obtained from the right eye were considered to belong to putative novel bacterial species and taxa as their similarity to GenBank data was below $98.75 \%$. The isolates were considered to be Pasteurellaceae bacterium, Corynebacterium ciconiae, Cardiobacteriaceae bacterium, Actinomyces sp., and Dermabacteraceae bacterium. The only isolate from the left eye was identified as Psychrobacter pygoscelis. The cytological analysis demonstrated cell infiltrates composed mostly of degenerate heterophils, reactive macrophages, plasma cells, lymphocytes, and eosinophils. Based on histopathological findings, the lesion was defined as typical pyogranulomatous panophthalmitis. Immunohistochemistry demonstrated that the granuloma was positive for TNF-a, IL-4, MMP-9, IL-1ß, and IL-6. This is the first documented report of unilateral pyogranulomatous panophthalmitis in a Gentoo penguin chick, living in its natural habitat in Antarctica. This report also describes the isolation of four bacteria from the infected eye, which are considered to belong to novel Genus, species, or taxa. The primary bacterial pathogen that caused the ocular lesion was not able to be detected and remains unclear.

\section{Introduction}

Gentoo penguins (Pygoscelis papua) have a circumpolar distribution, and usually nest in small colonies on the sub-Antarctic islands and Antarctic Peninsula (González-Acuña et al. 2013). Since 2000, this species has been listed as near-threatened and only very limited information is available on its bacterial diseases (Barbosa and Palacios 2009; González-Acuña et al. 2013).

Eyesight is of critical importance for penguins as it aids in migration, orientation, and foraging (Nesterova et al. 2010). Thus, vision disorders adversely affect the capability of these animals to adapt to their physical and social environment. While numerous bacteria, viruses, fungi, and parasites have been isolated from diseases of the avian ocular surface (Griggs 2019), only a few studies are available on the ophthalmic parameters of several penguin species, including ocular bacterial flora, intraocular pressure, and tear production( Suburo et al. 1988; Martin 1999; Swinger et al. 2009; Nesterova et al. 2010; Bliss et al. 2015; Sila et al. 2015). In a study conducted by Swinger et al. (2009), the ocular bacterial flora and ophthalmic parameters of 28 captive penguins kept at a zoo were investigated. However, to our knowledge, there is no published study on the ocular infections of penguins.

In general, cultural methods and histopathological, cytological and immunohistochemical analyses are employed to diagnose and determine the aetiology of ocular infections, and most often these different methods are used together.

Isolation of bacteria from cases of infection is carried out by cultural methods. The isolates recovered are identified at the species level by means of phenotypic tests and molecular analyses (Quinn 2011). It is 
common to use $16 \mathrm{~S}$ rRNA gene sequencing for molecular analysis. Especially when identifying novel bacteria species, the cut-off value is set as $98.70 \%$ (Chun et al. 2018; CLSI 2018). Panophthalmitis is an inflammation of all layers of the eye, including the intraocular structures (Chen et al. 2017). Reports of ocular cytology findings are rare in the field of veterinary medicine, except for reports related to canine, feline, and equine conjunctival cells (Barnes and Grahn 2007; Perazzi et al. 2017; Bayram et al. 2019; Proietto et al. 2019), which are well-defined. As a quick-resulting technique, which produces good quality preparations, exfoliative cytology can be used efficiently together with bacterial culture for the diagnosis of ocular infections. Ocular infections are associated with increased levels of proinflammatory cytokines, such as IL-1 1 , IL-la, IL-6, IL-8, TNF-a, and certain proteolytic enzymes (matrix metalloproteinases, MMPs) in the lacrimal fluid.

This study was aimed at presenting the results of the microbiological, cytological, histopathological, and immunohistochemical analyses of ocular samples taken from a Gentoo penguin chick (Pygoscelis papua) with pyogranulomatous panophthalmitis. These samples were taken from the right and left eyes of a penguin by Professor Latife ÇAKIR BAYRAM during the Third National Antarctic Scientific Expedition (TAE3), made to Antarctica (Ardley Island, King George Island) within the framework of the bilateral cooperation project signed between Turkey and Chile.

\section{Materials And Methods}

\section{Ocular Samples}

The ocular samples used in this study were taken from a Gentoo penguin (Pygoscelis papua) between 4 January and 9 February 2019, on King George Island, Ardley Island in Antarctica (62 13' S; 58 54' W) (Fig. 1). A bilateral cooperation project titled "The cytological, microbiological and ophthalmic evaluation of samples of ocular surface from the Antarctic Peninsula penguins" (Instituto Antártico Chileno, INACH, Antarctic Scientific Expedition, ECA 55) was agreed to be implemented under the framework of the Third National Antarctic Scientific Expedition (TAE3), made in the 2018-2019 period and organised by the Polar Research Centre (PolRec) of Istanbul Technical University. The ocular samples examined in the present study were collected at the location indicated above.

Approvals regarding entrance to the specially protected area of the Antarctic (Antarctic Specially Protected Area, ASPA, No: 150, Permit N- 21- 2019) and for collecting eye samples from the penguins (Antarctic Specially Protected Area, ASPA, No: 150, Permit N- 07- 2019) were provided by the Turkish Antarctic Program.

\section{Capture and handling of the penguin}

The capture and handling of the penguin were performed as described by González-Acuña et al. 2013 and in accordance with the standard methods laid down for the Ecosystem Monitoring Programme by the Commission for the Conservation of the Antarctic Marine Life Resources (CCAMLR 2004). For the sampling procedure, the penguin was restrained in an upright vertical position by applying gentle pressure to its wings, base of skull, and beak. During sampling, the penguin was maintained manually in a facedown position.

\section{Sampling}


In situ examination of the right eye demonstrated the presence of a reddish-orange coloured, granulation tissue-like, proliferative and exuberant lesion on the ocular surface. The movement of the nictitating membrane was not observed due to this lesion. The proliferative tissue was determined to occupy the cornea and other parts of the eyeball (Fig. 2). An extensive exuberant mass, which occupied the anterior chamber, made it impossible to identify the intraocular structure. No macroscopic lesion was observed in the left eye.

Using a sterile scalpel, samples were taken from the mass in the right eye into $1 \mathrm{ml}$ of sterile distilled water for microbiological analysis, Cytospin collection fluid (Cytobrush, Gynobrush Plus, Germany) for cytological analysis, and $70 \%$ ethyl alcohol for histopathological analysis. The left eye of the penguin, which appeared to be healthy, was sampled for microbiological and cytological analyses. The microbiological samples were collected with a swab into Stuart's transport medium, whilst the cytological samples were collected either by brushing into Cytospin collection fluid or by the membrane filter technique (cellulose-acetate filter papers; Sartorius, HAWG 047 AO, 3x4 mm in diameter, 0.45-micrometer pore size) into 70\% ethyl alcohol (Bolzan et al. 2005; Singh et al. 2005). The swab and brush were gently rolled over the cornea on the limbus, such that the palpebral and forniceal conjunctiva, anterior to the third eyelid, were also sampled.

Filter strips with a pointed tip on one end were placed on the superior, ventral temporal bulbar conjunctiva, near the limbus as described by Bolzan et al. (2005) and Singh et al. (2005) with minor modifications. The strips were removed with a peeling motion, and the samples were immediately transferred to the laboratory at the Professor Julio Escudero Base, King George Island, Antarctica. The samples were stored at $4^{\circ} \mathrm{C}$ and examined within 2 weeks.

\section{Bacteriological analysis}

The ocular tissue sample taken into distilled water for bacteriological analysis was broken into small pieces by shaking. Slides were prepared from the resulting suspension, and were stained with the Gram and ZiehlNeelsen techniques. $50 \mu \mathrm{l}$ of the suspension was directly inoculated onto three plates of blood agar (Blood agar base No: 2, CM0271, Oxoid, Waltham, MA, USA/containing 7\% sheep blood) added $2 \%$ of $\mathrm{NaCl}$ (Merck, Germany). The swab sample taken from the left eye was directly inoculated onto three blood agar plates. The inoculated plates were incubated at $37^{\circ} \mathrm{C}$ under aerobic, microaerobic and anaerobic conditions for 2-3 days. At the end of the incubation period, the colonies were examined both macroscopically (for size, colour, odour, haemolysis, etc.) and microscopically. Each different type of colony that had grown on the blood agar was subcultured onto sheep blood agar for purification. Both phenotypic tests (Gram staining, catalase, oxidase, motility and carbohydrate fermentation tests), as described by Quinn et al. (2011), and molecular analyses (16S rRNA gene sequence analysis) were performed for the identification of the recovered isolates at the species or genus level. The recovered isolates are stored in Brucella broth containing $15 \%$ glycerine at $-84^{\circ} \mathrm{C}$, as part of the culture collection of the Microbiology Department of Erciyes University, Faculty of Veterinary Medicine.

\section{Mycological analysis}

For the detection of possible fungal agents, samples from both eyes were inoculated onto Sabouraud dextrose agar (SDA, CM0041, Oxoid, United Kingdom). The inoculated plates were incubated at $22^{\circ} \mathrm{C}$ and $37^{\circ} \mathrm{C}$ under aerobic conditions for 2-3 days. 


\section{Molecular identification}

\section{DNA extraction}

The DNeasy UltraClean Microbial Kit (12224-50, Qiagen, USA) was used for DNA extraction from the bacterial isolates.

\section{S rRNA sequencing}

The species identification of the isolates was made by means of 16S rRNA gene sequence analysis. Accordingly, four primers, including 27F and 1492R, and two internal primers 518R: ATT ACC GCG GCT GCT GG and 968F: AAC GCG GAA GAA CCT TAC) were used for the sequencing of the 1465 bp-fragment of $16 \mathrm{~S}$ rRNA. The PCR mixture used for the amplification of this $1465 \mathrm{bp}$-fragment was $25 \mu \mathrm{l}$ in volume and contained $12.2 \mu \mathrm{l}$ of molecular grade deionised water, $2.5 \mu \mathrm{l} 10 x$ PCR buffer, $2.5 \mu \mathrm{IgCl}_{2}(25 \mathrm{mM}), 0.5 \mu \mathrm{l}$ $10 \mathrm{mM}$ dNTP, $1 \mu \mathrm{l}$ of the forward primer $(10 \mathrm{pmol}), 1 \mu \mathrm{l}$ of the reverse primer $(10 \mathrm{pmol}), 0.3 \mu \mathrm{l}$ Taq DNA polymerase, and $5 \mu \mathrm{l}$ of the DNA recovered from the isolates $(25 \mathrm{ng} / \mu \mathrm{l})$. Amplification was performed as follows: initial denaturation at $94^{\circ} \mathrm{C}$ for 4 min followed by 35 cycles including denaturation at $94^{\circ} \mathrm{C}$ for 30 sec, primer annealing at $58^{\circ} \mathrm{C}$ for $30 \mathrm{sec}$, primer extension at $72^{\circ} \mathrm{C}$ for $1 \mathrm{~min}$, and a final extension at $72^{\circ} \mathrm{C}$ for 6 min. The PCR products were run on agarose gel electrophoresis and those, which were of the appropriate size (1465 bp) and underwent 16S rRNA sequence analysis. The 16S rRNA gene was manually aligned with type strain sequences retrieved from EzBioCloud database (Yoon et al. 2017) following BLAST searches for fast identification.

\section{Evolutionary relationships of taxa}

Pairwise sequence similarities were calculated using the method recommended by Meier-Kolthoff et al. (2013b) for the 16S rRNA gene available via the GGDC web server (Meier-Kolthoff et al. 2013a) available at http://ggdc.dsmz.de/.

Phylogenies were inferred by the GGDC web server (Meier-Kolthoff et al. 2013a) available at http://ggdc.dsmz.de/ using the DSMZ phylogenomics pipeline (Meier-Kolthoff et al. 2014) adapted to single genes. A multiple sequence alignment was created with MUSCLE (Edgar, 2004). Maximum likelihood (ML) and maximum parsimony (MP) trees were inferred from the alignment with RAxML (Stamatakis 2014) and TNT (Goloboff et al. 2008), respectively. For ML, rapid bootstrapping in conjunction with the autoMRE bootstopping criterion (Pattengale et al. 2010) and subsequent search for the best tree was used; for MP, 1000 bootstrapping replicates were used in conjunction with tree-bisection-and-reconnection branch swapping and ten random sequence addition replicates. The sequences were checked for a compositional bias using the $\mathrm{X}^{2}$ test as implemented in PAUP* (Swofford 2002).

\section{Antibacterial susceptibility testing}

The susceptibilities of the bacterial isolates to amoxicillin/clavulanic acid (AMC, $30 \mu \mathrm{g})$, ampicillin (AM, 10 $\mu \mathrm{g})$, azithromycin (AZM, $15 \mu \mathrm{g}$ ), enrofloxacin (ENR, $5 \mu \mathrm{g})$, gentamicin (CN, $10 \mu \mathrm{g})$, levofloxacin (LEV, $5 \mu \mathrm{g})$, and tetracycline $(\mathrm{TE}, 30 \mu \mathrm{g})$ were determined using the disc diffusion method (Clinical and Laboratory Standards 
Institute, 2018). The antimicrobial discs were purchased from Bioanalyse, TURKEY. Due to we could not identify the isolates at the species level, the disk diffusion test results of our isolates were evaluated by using the criteria published by the Clinical and Laboratory Standards Institute (CLSI 2018 and CLSI 2019) for Enterobacteriaceae and staphylococci, respectively. Escherichia coli (E. coli) ATCC 25922 and Staphylococcus aureus ATCC 25923 were used as reference strains for the susceptibility tests.

\section{Exfoliative Cytology}

\section{Cytospin Technique}

The tissue samples taken from the proliferative mass into Cytospin collection fluid for cytological analysis were agitated on a vortex mixer. Cytocentrifuged slides were prepared from this agitated suspension. The brush sample taken from the left eye was also transferred into a fixative solution (Cytospin collection fluid, Thermo Shandon 6768001, USA).

With an aim to evaluate cell morphology, Cytospin slides were prepared from ocular surface samples by cytocentrifugation (Cytospin 4, ThermoShandon, Pittsburgh, PA, USA) at 1000 rpm for 5 min, using disposable plastic chambers (Cytofunnel, ThermoShandon) and glass slides (Cytoslide, ThermoShandon). Wet cytocentrifuged slides were dried and then stained with the Haematoxylin-Eosin (HE) (Scott and Penny 1993) and Diff-Quik methods (Richard Allan Scientific, Thermo Electron Corporation, 9990700, USA). The slides were mounted with mounting medium (Merck, Germany).

\section{Impression Cytology}

This method was performed as described by Bolzan et al. (2005) with minor modifications. Briefly, the strips were immediately placed in individual Eppendorf tubes containing $95 \%$ ethyl alcohol. Next, the strips were stained with Periodic Acid-Schiff (PAS) x Haematoxylin, as described by Nelson et al. (1983) with some modifications such as the use of a filter with a pore size of $0.45 \mu \mathrm{m}$ and sodium metabisulfite. The samples were hydrated with distilled water for $5 \mathrm{~min}$, immersed in $0.5 \%$ periodic acid for $5 \mathrm{~min}$, washed in distilled water for $5 \mathrm{~min}$, immersed in Schiff's reagent for $5 \mathrm{~min}$, washed under running water for $5 \mathrm{~min}$, immersed in sodium metabisulfite (three successive immersions, each for $5 \mathrm{~min}$ ), washed under running water for $10 \mathrm{~min}$, counterstained with Harris' haematoxylin for $1 \mathrm{~min}$, and washed under running water for $5 \mathrm{~min}$. After these steps, the samples were dehydrated in $95 \%$ and $100 \%$ ethyl alcohol (two successive immersions, each for 1 $\mathrm{min}$ ) and immersed in xylene (two successive immersions, each for $5 \mathrm{~min}$ ). Finally, they were mounted onto slides in a way that the cells were faced upwards, and were cover-slipped using mounting medium (Bolzan et al. 2005).

\section{Histopathological analyses}

Tissue samples underwent routine processing and were embedded in paraffin. Nine 5- to 6- $\mu \mathrm{m}$-thick serial tissue sections, representative of the entire tissue sample, were cut from the paraffin block and mounted onto glass slides. Each paraffin section was stained with H\&E, and the Brown-Brenn Gram (Pritt et al. 2006), Grocott methamine silver stain (Polyscience) (Wright et al. 2017), acid-fast stain, and immunohistochemical stains. Furthermore, the streptavidin-biotin peroxidase (SABP) complex method (Invitrogen, USA) was 
performed using five different antibodies, including those against TNF-a, IL-4, MMP-9, IL-1 $\beta$, and IL-6. While Chicken Bursa Fabricius tissue sample was used as a positive control, Phosphate buffer solution (PBS) was used instead of primary antibody in the negative control slides. In addition, since there is no commercially produced antibody specific to penguins, antibodies that are routinely used for immunohistochemical staining in poultry were used in the current study. The primary antibodies used in the present study are shown in Table S1. Immunoreactions were visualized using aminoethyl carbazole chromogen (AEC, Invitrogen, USA) (Adhikari et al. 2018; Balouria et al. 2019). The immunostaining results were evaluated by scoring the intensity of colour development, and were graded as strong, moderate or mild staining, paying special attention to the pattern and distribution of positive immunostaining in the histological sections (Fedchenko and Reifenrath 2014).

All cytological, histopathological and immunohistochemical $(\mathrm{IHC})$ slides were imaged with a digital camera (Olympus DP71) and digital programmers (DP Controller and the DP Manager) fitted to a microscope (BX-51, Olympus, Tokyo, Japan) (minimum of 4 fields per slide, using x10, x40, and x100 objective lenses).

\section{Electron microscopic examination of the isolates}

All isolates were imaged by the transmission electron microscopy (TEM) and scanning electron microscopy (SEM) for the examination of the individual cell morphologies, at Erciyes University Technology Research and Application Center (ERU-TAUM, Kayseri, Turkiye). For this purpose, 24-48 hour fresh cultures belong to isolates grown in the solid medium were used.

\section{Results}

\section{Bacteriological findings}

While the samples were found to be negative for acid-resistant bacteria by Ziehl-Neelsen staining, they were observed to contain numerous Gram-negative coccobacilli and Gram-positive pleomorphic bacilli by Gram staining. The culture method yielded a total of 6 isolates, 5 from the right eye, and one from the left eye of the penguin. The isolates recovered from the right eye were numbered as TAE3-ERU1, TAE3-ERU2, TAE3-ERU3, TAE3-ERU4, TAE3-ERU5, and the isolate from the left eye was numbered as TAE3-ERU6.

The phenotypic and physiological characteristics of the isolates are presented in Table 1.

\section{S rRNA gene sequence analysis}

Based on the BLAST (basic local alignment search tool) and EzBioCloud database searches of the 16S rRNA gene sequencing results of the isolates recovered from the right and left eye demonstrated that 2 of 5 isolates could be done species-level identification. Other isolates, which were found below threshold (98.7\%) with similarities rate of the type strain, could not be identified as species-level. 16S rRNA gene sequence similarity of our isolates is given in Table 2. Each sequence was deposited in the GenBank database with MT444110MT444114, and MT674807 for TAE3-ERU1 - TAE3-ERU5 and TAE3-ERU6, respectively.

\section{Mycological analysis}


All of the samples examined were found to be negative for fungi.

\section{Phylogenetic analysis}

According to the phylogenetic analysis result;

- TAE3-ERU1 was determined to be close to Bisgard Taxon 14 and also this isolate could be a new genus in Pasteurellaceae

- TAE3-ERU2 was determined to be close to Corynebacterium ciconiae CCUG 47525 type strain.

- TAE3-ERU3 was determined to be close to Rappaport and Suttonella in the Cardiobacteriaceae family,

- TAE3-ERU4, determined to be close the Actinomyces,

- TAE3-ERU5, found to close in the Devriesea genus in the Dermabacteraceae family

- TAE3-ERU6 was determined to be close to Psychrobacter pygoscelis I-STPP5b type strain.

Detailed information about phylogenetic analysis was given below phylogenetic trees of isolates in Fig. S1Fig. S6.

\section{Antibacterial susceptibility testing}

Antibacterial susceptibility tests showed that five of the isolates were susceptible to all of the antibiotics tested (AMC, AMP, TE, LEV, ENR, AZM and CN). On the other hand, isolate TAE3-ERU5, belonging to the family Dermabacteraceae, was determined to be susceptible to AMC, AMP, TE, LEV, ENR and AZM, and resistant to gentamicin.

\section{Pathological findings}

\section{Cytological findings}

Abundant heterophils, a few aggregates of degenerate heterophils, and numerous intra/extracellular Grampositive filamentous and Gram-negative coccobacilli and bacilli were observed in the cytospin slides, which were prepared from the proliferative mass in the right eye and stained with Periodic acid-Schiff (PAS), Haematoxylin and Eosin (H\&E) and Papanicolaou (PAP) staining techniques (Figure S7 (A-I)). Mixed cell infiltration, composed of mononuclear cells and squamous epithelial cells, degenerate heterophils and macrophages, intracellular bacteria in the cytoplasm of macrophages and karyolytic heterophils, was detected. Bizarre cells with two large kidney-shaped nuclei were also observed.

Furthermore, distinct squamous conjunctival metaplasia, characterized by mucus, keratin, and pyknotic cells with an enlarged cytoplasm and a decreased nucleus/cytoplasm ratio, was observed in some areas. In the impression slides, only abundant heterophil leukocytes and bacteria were observed, and goblet cells were not detected

In the cytospin slides prepared from the sample taken from the left eye, columnar epithelial cells, small and round conjunctival cells, and non-cornified squamous corneal epithelial cells, were common. It was observed that the nucleus/cytoplasm ratio of these eosinophilic cells had not altered and that the cells were similar to 
each other in shape and size. The examination of the impression slides revealed numerous heterophils, lymphocytes, macrophages, goblet cells and extracellular bacteria. (Fig. S7 (A-I)).

\section{Histopathological findings}

Histopathological examination showed that the proliferative mass, characterized by necrotic debris, cell infiltration, and numerous pleomorphic and filamentous branching bacilli, and sulfur granules, had replaced all layers of the anterior chamber of the eye. It was observed that the surface epithelium of the cornea had completely disappeared and the stroma was necrotic. Dense inflammatory cell infiltration had extended to the deep stromal layer of the cornea. The anterior chamber was completely displaced by necrotic and pyogranulomatous lesion. Furthermore, fibroblasts and fibrocytes were found at significantly higher numbers in the anterior chamber of the eye. Histopathologically, the reddish-orange coloured proliferative mass was a typical pyogranuloma. The granuloma was mature and displayed extensive coagulation necrosis at the centre with multinucleated giant cells palisading along the necrotic line. These giant cells were surrounded by an infiltration of numerous macrophages, heterophils, lymphocytes and fibroblasts, and few plasma cells and eosinophils (Fig. 3 A-E). Brown-Brenn staining demonstrated the clustering of club-like organisms comprised of numerous pleomorphic and filamentous Gram-positive bacteria within sulphur granules, which were surrounded by neutrophils and lymphocytes. Also, few small Gram-negative coccobacilli were also observed. Grocott-Gomori methenamine-silver staining revealed the presence of branched agents, characteristic of actinomycosis (Fig. S8). Fungi, and based on the results of Ziehl-Neelsen staining, acid-fast bacteria were detected neither within nor in the periphery of the granuloma. Furthermore, dysplastic alterations, including large hyperchromatic nuclei and binucleated cells with an increased nucleus/cytoplasm ratio and an irregular nucleus, were also observed. A histopathological section representative of the proliferative mass is shown in Fig. 3 (F-Q).

\section{Immunohistochemical findings}

Our immunohistochemical results demonstrated positive staining for matrix metalloproteinase-9 (MMP-9), proinflammatory cytokines such as tumour necrosis factor-alpha (TNFa), interleukin-1 beta (IL-1 $\beta$ ), and interleukin-6 (IL-6), and anti-inflammatory cytokine IL-4 (interleukin-4) (Fig. 3 (R-AB)). Immunoreactivity for IL1 $\beta$, (Fig. 3R-S) and IL-6 (Fig. 3V, W) was observed to be much more intense.

In the conjunctival epithelial and stromal cells of the cornea, strong IL-4 immunoexpression was detected (Fig. 3T). Cytoplasmic immunoreactivity for IL-4 and MMP-9 was observed to be very strong in the regions of the conjunctiva where macrophages and giant cells and necrosis were intense. (Fig. 3Y, Z, X).

Moderate cytoplasmic immunoexpression of MMP-9 was detected in the epithelial cells of the cornea. While the granuloma, which was composed of heterophils, macrophages, and multinucleated giant cells, showed positive immunoreactivity for IL-1 $\beta, T N F a$, and IL-6, the immunoreactivity for these proinflammatory cytokines was moderate in the epithelial cells of the cornea and sclera (Fig. 3R, S; U-Y, AA, AB). Immunostained slides prepared from the brush sample of the left eye were used as a control for the evaluation of MMP-9, TNF- $a$, IL4, IL-1B, and IL-6 positivity. The immunochemical staining results of the slides prepared from the right and left eyes are shown in Fig. 3R-AB. 


\section{Morphological findings of the isolates}

The morphological appearance of the bacterial isolates by light microscope, Transmission electron microscope, and Scanning electron microscopy SEM are presented in Fig. 4.

\section{Discussion}

In the present study, an ocular lesion occupying the right eye of a Gentoo penguin chick, living in its natural habitat (Antarctic Peninsula), was defined as pyogranulomatous panophthalmitis, based on cytological, histopathological and immunohistochemical analyses. Bacteria, which were unable to be identified at species level, but classified under 5 different genera, and considered belonging to putative novel taxa, genera and species, were isolated from the ocular lesion. Furthermore, Psychrobacter pygoscelis was isolated from the seemingly healthy left eye of the same animal. To our knowledge, in respect of its particularities described, the present study is the first and only of its kind. The ocular lesions of non-captive raptors are generally caused by trauma (Labelle et al. 2012; Moore et al. 2018). Previous ophthalmologic research is known to have been carried out mostly in captive raptors, psittacines and penguins kept at zoos. Previous ophthalmologic studies, conducted in penguins, either professionally cared for at zoological institutes or kept at aquariums, have focussed on ophthalmological parameters such as tear production and intraocular pressure (Swinger et al. 2009; Bliss et al. 2015; Gonzalez-Alonso-Alegre et al. 2015; Sheldon et al. 2017). Ophthalmic lesions reported to have been detected in captive penguins are limited to conjunctivitis (Leigue et al. 2016), keratoconjunctivitis (Jencek et al. 2012), and cataract ( Swinger et al. 2009; Bliss et al. 2015; Church et al. 2018). On the other hand, no information is available on ophthalmic lesions or infections in non-captive penguins living in their natural habitat, including the Gentoo penguin. Several diagnostic tests are required to be performed to determine the aetiology of ocular lesions and manage ocular diseases in avian species ( Michalle Willis and Wilkie, 1999a, 1999b; Meekins et al. 2015; Griggs, 2019).Exfoliative cytology (cytospin centrifugation together with brush cytology and impression cytology) of the corneal and conjunctival epithelium is a routine complementary diagnostic method (Perazzi et al. 2017), which is successfully used in various animal species (Bolzan et al. 2005; Perazzi et al. 2017; Proietto et al. 2019). An initial diagnosis can be made by the detection of the cell population and the presence of infectious agents via exfoliative cytology (Bolzan et al. 2005; Cakir et al. 2014).In the present study, cytological analysis of the samples taken by the cytobrush and membrane filter techniques from the right eye of the penguin demonstrated ocular surface cells, infiltrating reactive cells and the presence of bacteria with different morphological features (Fig. S7). In agreement with the findings of previous reports for cytospin slides prepared from samples of animals with keratoconjunctivitis (Cakir et al. 2014), the present study revealed the presence of binucleated epithelial cells. The presence of binucleated cells is considered as an indicator of reactive changes in areas of severe chronic inflammation. On the other hand, the cytological analysis of the sample taken from the left eye of the same animal demonstrated normal ocular surface cells, similar to descriptions made in previous literature reports (Bolzan et al. 2005; Athanasiou et al. 2018). In the present study, based on histopathological examination (Fig. 3), the lesion in the right eye of the penguin was defined as pyogranulomatous panophthalmitis. To the authors' knowledge, there is no previous report on the diagnosis of panophthalmitis in captive or non-captive penguins. However, reports have been published on Pseudomonas aeruginosa-induced cases of unilateral panophthalmitis in turkeys (Nakamura and Abe 1987; Aziz and Barnes 2001), and E. coli-induced cases of 
colisepticaemia-related panophthalmitis in chickens. The cellular nature of the panophthalmitis cases detected in chickens was described as being granulomatous (Gross 1957). Similarly, in the present study, based on the cellular characteristics determined by histopathological examination, panophthalmitis detected in the right eye of the penguin was defined as being pyogranulomatous. Granulomas are generally characterized by well-delineated focal lesions that develop in the event of the immune system's failure to eliminate infectious microorganisms. These lesions primarily contain mononuclear phagocytic cells, macrophages (histiocytes), epithelioid cells and multinucleated giant cells (Williams and Williams 1983).While bacterial and fungal granulomatous lesions associated with Mycobacteria spp., Salmonella spp., Escherichia coli, Nocardia spp., Actinomyces spp. and Aspergillus spp. have been detected in various systems of avian species, those associated with Nocardia spp. and Actinomyces spp. have been reported only rarely (Park and Jaensch 2009). In the current study, while Brown-Brenn staining of the ocular tissue sections prepared from the lesion demonstrated the presence of many Gram-positive filamentous pleomorphic bacteria, and Gram-negative coccobacilli and pleomorphic bacteria, GMS staining displayed the presence of branching filamentous bacteria surrounded by intense inflammatory cell infiltration, typically referred to as sulphur granules (Fig. S8). The culture method enabled the isolation of bacteria from the ocular lesion, which were determined as belonging to 5 different genera, and included Pasteurellaceae, Corynebacterium ciconiae, Cardiobacteriaceae, Actinomyces sp., and Dermabacteraceae. Although sulfur granules have been reported to occur in infections caused by agents such as Nocardia spp., Staphylococcus spp., and Streptomyces spp., (Wang et al. 2012), these agents could not be isolated in this study. In addition, filamentous structures characteristic of Actinomyces were detected in sulfur granules in the GMS staining. So these agents (Nocardia spp., Staphylococcus spp., and Streptomyces spp.) have been eliminated as possible aetiological agents based on these results. Also, no fungal growth having been observed upon mycological analysis, and the absence of acid-resistant bacteria having been confirmed by Ziehl-Neelsen staining in the histopathological and microbiological analyses eliminated the possibility of Mycobacteria spp. and Aspergillus spp. being involved in the aetiology of the granuloma. The bacteria, which were isolated by the culture method and identified as Corynebacterium ciconiae, Actinomyces sp. and Dermabacteraceae bacterium, all belong to the class Actinobacteria and cause granulomatous inflammation. Therefore, the granulomatous inflammation detected in the right eye of the penguin is considered most probably to have been caused by these particular organisms. There is only one previous study reporting granulomatous inflammation in penguins, which describes adenitis of the salt gland in blue penguins (Eudyptula minor) inhabiting New Zealand (Suepaul et al. 2010). Thus, to the authors' knowledge, this is the first study to report unilateral pyogranulomatous panophthalmitis in a Gentoo penguin chick. Many different bacteria, viruses, fungi and parasites have been isolated from cases of ocular surface disease in various avian species (Michelle Willis and Wilkie 1999). Given that ocular lesions occur as findings of either local or systemic infections, in general it is hard to determine whether the isolated organism is the primary cause of the lesion or not (Griggs 2019).

As is the case with mammalian cytokines, avian cytokines are also involved in the host immune response against infectious agents (Xu et al. 2019). MMPs are the key effectors and regulators of inflammation, wound healing, tissue regeneration and pathogenesis (Petznick et al. 2013). The correlation between certain inflammatory cytokines, including tumour necrosis factor-alpha (TNFa) and interleukin-1 (IL-1) (Shoshani et al. 2005; Cole et al. 2005; Kaiser and Stäheli, 2013) and MMP-9 (Shyu et al. 2019) has been demonstrated in 
previous research on corneal diseases such as corneal ulcer and keratitis ( Shoshani et al. 2005; Cole et al. 2005; Kaiser and Stäheli, 2013). Similar to previous reports in other avian species (Kaiser and Stäheli, 2013), it was also determined in the Gentoo penguin that pyogranulomatous panophthalmitis was associated with high level of MM-9 secretion and strong TNFa, IL-1 1 , IL-6 and IL-4 immunoreactivity in response to the inflammatory stimulus (Fig. 3). In the present study, based on strong TNFa, IL-1 $\beta$, IL-6, IL-4 and MMP-9 immunopositivity having been detected in the inflammatory cells, it was considered that the indicated cytokines and enzyme could have accompanied the development of the granuloma in the eye diagnosed with mixed bacterial infection.

Staphylococcus spp., Streptococcus spp., Clostridium spp., Erysipelothrix spp., Mycoplasma spp., Moraxella spp., Chlamydophila psittaci, Salmonella spp., Bordotella spp., Escherichia coli, Pseudomonas spp., Actinobacillus spp., Pasteurella spp. and Mycobacterium spp. (Griggs, 2019) have been reported as ocular pathogens in avian species. Swinger et al. (2009) investigated the bacterial flora of the normal ocular surface as well as lacrimal secretion and intraocular pressure in the Humboldt penguin. These researchers reported to have isolated Corynebacterium spp., Staphylococcus spp., Moraxella spp. and Pasteurella spp. from the eyes of healthy captive penguins kept in freshwater and saltwater habitats at the Brookfield Zoo (Chicago, Illinois, $\mathrm{ABD}$ ) and indicated that the most prevalent bacteria were Corynebacterium spp. and Staphylococcus spp. Similarly, Dupont et al. (1994) reported to have frequently isolated these two bacteria (Corynebacterium spp. and Staphylococcus spp.) alongside Gram-positive bacteria such as Bacillus spp. and Streptococcus spp., Gram-negative bacteria such as Acinetobacterspp., Escherichia coli, Klebsiella oxytoca and Enterobacter spp., and fungi such as Aspergillus and Cladosporium spp. from the eyes of healthy raptors.

The microorganisms isolated from the eyes of a Gentoo penguin chick in the present study differ from those reported to have been isolated from the eyes of mammals and exotic birds in previous studies ( Silvanose et al. 2001; Cullen, 2003; Bonelli et al. 2014; Cakir et al. 2014; Sala et al. 2016). Furthermore, the microorganisms isolated in the present study have been determined to differ from the bacteria reported to have been detected in freshwater samples from the same location (Jara et al. 2020).

Today, the identification of microbial agents isolated from cases of infection by the culture method and molecular techniques is particularly significant for the establishment of treatment protocols (Miller et al. 2009). While the similarity of 16 S rDNA gene sequences between two strains serves as a simple yet reliable criterion for the identification of novel strains, phylogenetic analysis has become the key to elucidate the evolutional relationship between related taxa ( Ludwig and Klenk 2001; Kim and Chun 2014).

Six bacteria, referred to as TAE3-ERU1/TAE3-ERU6, were isolated from samples taken from the right and left eyes of the penguin using the culture method. These bacteria underwent detailed investigation, including phenotypic analysis such as Gram staining, as well as molecular analysis and electron microscopic examination.

TAE3-ERU1, which was recovered from the right eye and identified as belonging to the family Pasteurellaceae, was $98.65 \%$ genetically similar to Bisgaard Taxon 14 according to the Genbank Database, and was found to be positioned between Bisgaard Taxon 14 and Bisgaard Taxon 32, based on phylogenetic analysis (Fig. S1). Based on EzBioCloud database, 16S rRNA similarity of TAE3-ERU1 was found to Pasteurella testudines

Page $12 / 30$ 
(94.22\%). For describing of a novel genus has to be as an approximately 5- $6 \%$ divergence in 16S rRNA gene sequence from its closest genus in taxonomy studies (Qin et al. 2014). Due to the similarity value of TAE3ERU1, we concluded that this isolate belonged to a novel genus in Pasteurellaceae family.

The family Pasteurellaceae includes 30 genera and 94 validly named species in current use (Bisgaard's taxa 2020; ICSP 2020; LPSN 2020a; Pasteurellacea 2020). This family also includes unidentified 55 taxa, known to have been isolated from various sources, which have been enumerated from 1 to 55 under the Bisgaard taxon (Bisgaard's taxa, 2020). Bisgaard Taxon 14 and Bisgaard Taxon 32 are known to be avian taxa (Christensen et al. 2003). Taxon 14 is reported to have been isolated from lesions of the upper respiratory tract in ducks, turkeys, pigeons, geese and peacocks ( Bisgaard and Mutter, 1986; Bisgaard, 1993) and from cases of blepharoconjunctivitis in turkeys (Günther et al. 2006). Furthermore, Taxon 32 has been isolated from cases of pneumonia and conjunctivitis in pigeons and buzzards (Christensen et al. 2003).

TAE3-ERU2 was identified as a Corynebacterium ciconiae with 99.05\%. The genus Corynebacterium comprises 125 species (LPSN, 2020b) of medical, veterinary or biotechnological importance, which have been isolated from various sources (Dorella et al. 2006). Members of this genus are not only part of the normal microbiota of the skin and mucosa in a variety of hosts, but can also be found in soil, water and the environment (Ott, 2018).

TAE3-ERU3 was found to show $94.70 \%$ similarity to the feline oral taxon of Cardiobacterium sp., according to the Genbank database. Also, Based on the EzBioCloud database, this isolate was close to Pasteurella testudines (94.22\%) and Rappaport israeli (93.92\%) and was determined a member of the Cardiobacteriaceae family. Therefore, based on phylogenetic analysis, it was determined that isolate TAE3-ERU3 could belong to a novel genus under the family Cardiobacteriaceae (Fig. S3). The family Cardiobacteriaceae includes three genera, namely, Cardiobacterium, Dichelobacter and Suttonella. In 2017, the species Rappaport israeli was isolated from human blood culture and was classified under a novel genus belonging to this family. However, no information is available on this novel genus in the LPSN database.

16S rRNA similarity of TAE3-ERU4, recovered from the right eye of the penguin, was found to Actinomyces liubingyangii with $\mathbf{9 7 . 4 0 \%}$. Phylogenetic analysis and similarity value of isolate are revealed isolate TAE3ERU4 to be a novel Actinomyces species (Fig. S4). There are almost 29 validly named Actinomyces species. Actinomyces species are found on the mucosal surfaces of many animals, and access deeper tissues by means of trauma, surgical procedures, and foreign substances that disrupt the mucosal barrier (Park and Jaensch 2009). Actinomyces sp. has also been isolated from a case of canine ulcerative keratitis (Sherman et al. 2013).

16S rRNA similarity of TAE3-ERU5 was found to belong to Dermabacteraceae, and taxonomically, was determined to show $96.88 \%$ similarity to Devriesa agamarum. Classified under the Actinobacteria family, Devriesa agamarum has been reported to be associated with dermatitis and septicaemia in reptiles. Phylogenetic analysis demonstrated that isolate TAE3-ERU5 could belong to a novel genus in the Dermabacteraceae family, however, it is a different clade from Devriesea, Helcobacillus, and Dermabacter genus. (Fig. S5). 
TAE3-ERU6 recovered from the healthy left eye of the penguin in the present study was identified as Psychrobacter pygoscelis on the basis that it showed $99.11 \%$ similarity to this species upon undergoing $16 \mathrm{~S}$ rRNA sequence analysis. The number of newly described Psychrobacter species has increased in parallel with the increased number of discoveries related to polar and marine habitats. Today, the genus Psychrobacter includes 41 validly named species (Genus Psychrobacter 2020).

Isolates TAE3-ERU2, TAE3-ERU4 and TAE3-ERU5 (Corynebacterium ciconiae, Actinomyces sp., Dermabacteraceae), also recovered from the right eye, were determined to belong to the family Actinobacteria. While marine environments are known to be a rich source of Actinobacteria, bacteria in this family are reported to be capable of producing various active secondary metabolites (Yuan et al. 2014). Previous studies conducted in the Antarctic region (Li et al. 2010) and nearby Chile (Claverías et al. 2015; Undabarrena et al. 2016) have demonstrated the presence of Actinobacteria in marine sediment and soil (Lee et al. 2012). Claverias et al. (2015), who isolated Actinobacteria in Chile, investigated the potential of these bacteria producing antibacterial substances and reported that Actinobacteria in the marine sediment could be cultured and were richly diverse. Undabarrena et al. (2016) reported to have detected bacteria belonging to the families Dermabacteraceae and Corynebacteriaceae, under which the isolates TAE3-ERU5 and TAE3-ERU2 recovered in the present study were classified, among the Actinobacteria they isolated from marine sediment in Chile. Furthermore, other members of the family Actinobacteria, including Arthrobacter spp. Brevibacterium spp. and Corynebacterium spp. have also been reported to exist in the dry valleys of Antarctica (Cary et al. 2010).

All of the 5 isolates recovered in the present study were determined to be susceptible to each of the 7 antibiotics tested. Only the isolate belonging to the family Dermabacteraceae was found to be resistant to gentamicin. This high antibacterial susceptibility was attributed to penguins not being exposed to antibiotics. Several studies have been conducted to investigate the antibacterial susceptibility of various bacteria isolated from penguin faeces and water samples in the Arctic region (Bonnedahl et al. 2008; Miller et al. 2009; Rabbia et al. 2016; Cerdà-Cuéllar et al. 2019; Jara et al. 2020). Although literature reports have been published on bacterial isolation from cases of infection in penguins in the Antarctic region (Nievas et al. 2007), no information is available on the antibacterial susceptibility of these isolates.

Today, only very few geographical regions, such as the Antarctic, are free from direct and indirect contact with human populations and domestic animals (Barbosa and Palacios 2009). In a recent study, in which bacteria were isolated from freshwater samples pertaining to different regions of the Antarctic Peninsula that were either subjected to or free from human contact and effect, Jara et al. (2020) assessed the antibacterial susceptibility of these isolates. Accordingly, these researchers reported that the number of antibiotic-resistant bacteria and antibiotic resistance genes were higher in the regions that were affected by humans and wildlife, compared to the regions that were far from human and animal populations.

In the present study, bacteria of 5 different genera were isolated from the right eye of the penguin. Thus, it was not possible to identify the primary causative agent of the pyogranulomatous inflammation in the right eye. Cytological and histopathological analyses demonstrated pyogranuloma as a characteristic finding of Actinomyces sp. infection, and the extra- and intracellular presence of various other Gram-positive and Gramnegative bacteria was also determined in the ocular lesion. 


\section{Conclusions}

The concurrent isolation of 5 different bacteria from the case of unilateral panophthalmitis in the right eye of the penguin is considered to be very interesting. In the present study, the sample taken from the lesion in the right eye was directly inoculated onto solid medium, and based on the assessment of macroscopic and microscopic morphology, the intense growth of 5 different bacterial colonies was observed. Different types of colonies having been detected was attributed to direct inoculation having been performed with no prior enrichment. Four different putative novel bacteria, bearing the potential of being new genera, species or taxa, having been isolated from the lesion in the right eye, and Psychrobacter pygoscelis having been isolated from the left eye of the animal are considered to be indicative of the rich bacterial diversity in the habitat of the penguin. The severity of the lesion was considered to be related also to the age of the animal. Studies that include further molecular analysis and phenotypic tests for the identification of our isolates at the species level continue.

\section{Declarations}

\section{Funding}

Some parts of this study including bacteriological, cytological, histopathological, and immunohistochemical analyses of the ocular samples examined were financially supported by Rectorate of Erciyes University, Kayseri, Turkey and other part of this study including the 16S rRNA gene sequence analyses of the bacteria isolated was financially supported by Scientific and Technological Research Council of Turkey (TUBITAK; project number: 119Z847).

\section{Acknowledgements}

This study was carried out under the auspices of the Presidency of The Republic of Turkey, supported by the Ministry of Industry and Technology, and coordinated by the Polar Research Centre (PolReC) of Istanbul Technical University (ITU).

The authors would like to thank the Chilean Antarctic Institute (INACH-Instituto Antártico Chileno) and Chilean officials, specifically the INACH Project team led by Dr Rafael Medina, also including Dr Victor Neira Ramírez, Ph.D. student Gonzalo Barriga, and graduate student Felipe Berrios, for their valuable assistance during the fieldwork. The authors extend their special thanks to Dr José Retamales for enabling access to the excellent working facilities in Chile and Antarctica.

We also thank the staff of the Chilean Antarctic bases, namely, the Chilean Army Bernardo O'Higgins Base, Yelchoo Base, Professor Julio Escudero Base, the Chilean Navy Stations Arturo Prat, AP-41 Aquiles and Karpuj for their logistic support.

We are greatly indebted to the penguin groups of the Chilean Antarctic Expedition for their help in the fieldwork. Furthermore, we acknowledge Res. Assist. Capt. Sinan Yirmibesoglu of Istanbul Technical University, Maritime Faculty, for his map arrangement based on the processing of Copernicus Sentinel data 
[2020] included in the Norwegian Polar Institute's Quantarctica package, using the Sentinel Hub (Fig. 1). We thank Professor Dr. Ayhan Duzler for his assistance in taking electron microscope pictures of bacteria.

We also thank the Rectorate of Erciyes University for funding the bacteriological, cytological, histopathological, and immunohistochemical analyses of the ocular samples examined in this study. Finally, we extend our gratitude to the Scientific and Technological Research Council of Turkey (TUBITAK; project number: 119Z847) for financially supporting the 16S rRNA gene sequence analyses of the bacteria isolated in this study.

\section{Author Contributions}

Latife Cakir Bayram: designed the research and collected the samples from the field; Secil Abay and Fuat Aydin: performed the bacteriological analysis of the samples and PCR for the identification of bacteria and 16S rRNA gene sequencing and analysed antibacterial susceptibility of the isolates; Tolga Guvenc and Gorkem Ekebas: performed immunohistochemical staining of cytospin preparations and tissue sections; Latife Cakır Bayram: prepared cytospin slides, stained tissue sections and cytospin smears with special staining methods and interpreted the results; Izzet Burcin Saticioglu: prepared and evaluated the phylogenetic trees; Latife Cakir Bayram, Secil Abayand Fuat Aydin: discussed the results and wrote the manuscript.

\section{Data availability}

The data that support the findings of this study are available from the corresponding author upon reasonable request.

\section{Compliance with ethical standards}

\section{Consent for publication}

Not applicable

\section{Ethics approval}

Approvals regarding entrance to the specially protected area of the Antarctic (Antarctic Specially Protected Area, ASPA, No: 150, Permit N- 21- 2019) and for collecting eye samples from the penguins (Antarctic Specially Protected Area, ASPA, No: 150, Permit N- 07- 2019) were provided by the Turkish Antarctic Program.

\section{Conflict of Interest}

The authors declare that they have no conflict of interest.

\section{References}

1. Adhikari P, Cosby DE, Cox NA, Franca MS, Williams SM, Gogal RM, Ritz CW, Kim WK (2018) Effect of dietary fructooligosaccharide supplementation on internal organs Salmonella colonization, immune 
response, ileal morphology, and ileal immunohistochemistry in laying hens challenged with Salmonella enteritidis. Poult Sci 97: 2525-2533. https://doi.org/10.3382/ps/pey101

2. Athanasiou LV, Psemmas DE, Papaioannou N (2018) Conjunctival cytology assessment in dogs and cats. Sampling, diagnostic techniques and findings. J Hell Vet Med Soc 69: 701-710. https://doi.org/10.12681/jhvms.16382

3. Aziz TA, Barnes HJ (2001) Proceedings of the 52nd North-Central Avian Diseases Conference ., in: Panophthalmitis with Perforation of the Cornea in Poults Associated with Pseudomonas aeruginosa. $\mathrm{p}$. 61.

4. Balouria A, Deshmukh S, Banga HS, Ahmad A, Brar RS, Sodhi S (2019) Early migration pattern of Avibacterium paragallinarum in the nasal passage of experimentally infected chicken and Japanese quail by immunohistochemistry. Avian Pathol 48: 168-177. https://doi.org/10.1080/03079457.2018.1562153

5. Barbosa A, Palacios MJ (2009) Health of Antarctic birds: A review of their parasites, pathogens and diseases. Polar Biol 32: 1095. https://doi.org/10.1007/s00300-009-0640-3

6. Barnes LD, Grahn BH (2007). Actinomyces endophthalmitis and pneumonia in a dog. Can Vet J 48: 11551158.

7. Bayram LC, Gurbulak K, Gumussoy KS, Kutsal O (2019) The role of centrifuged liquid-based cytology in the evaluation of the endometrium in mares. Vet Arh 89: 743-770. https://doi.org/10.24099/vet.arhiv.0653

8. Bisgaard M (1993) Ecology and significance of pasteurellaceae in animals. Zentralblatt fur Bakteriol. 279: 7-26. https://doi.org/10.1016/S0934-8840(11)80487-1

9. Bisgaard M, Mutter R (1986) A new facultatively anaerobic gram-negative fermentative rod obtained from different pathological lesions in poultry and tentatively designated taxon 14. Avian Pathol 15:117-127. https://doi.org/10.1080/03079458608436271

10. Bisgaard's taxa. http://bisgaard.eu/index.php/magne/bisgaards-taxa\# (2020). (accessed 9.10.20).

11. Bliss CD, Aquino S, Woodhouse $S$ (2015) Ocular findings and reference values for selected ophthalmic diagnostic tests in the macaroni penguin (Eudyptes chrysolophus) and southern rockhopper penguin (Eudyptes chrysocome). Vet Ophthalmol 18: 86-93. https://doi.org/10.1111/vop.12123

12. Bolzan AA, Brunelli ATJ, Castro MB, Souza MA, Souza JL, Laus JL (2005) Conjunctival impression cytology in dogs. Vet Ophthalmol 8: 401-405. https://doi.org/10.1111/j.1463-5224.2005.00414.x

13. Bonelli F, Barsotti G, Attili AR, Mugnaini L, Cuteri V, Preziuso S, Corazza M, Preziuso G, Sgorbini M (2014) Conjunctival bacterial and fungal flora in clinically normal sheep. Vet Rec Open 1: e000017. https://doi.org/10.1136/vropen-2013-000017

14. Bonnedahl J, Olsen B, Waldenström J, Broman T, Jalava J, Huovinen P, Österblad M, (2008) Antibiotic susceptibility of faecal bacteria in Antarctic penguins. Polar Biol 31: 759-763. https://doi.org/10.1007/s00300-008-0430-3

15. Cakir L, Gumussoy K, Kutsal O, Tunc A (2014) Evaluation of brush cytology (cytospin technique) and cultural results in the diagnosis of keratoconjunctivitis in a goat herd. Ankara Üniversitesi Vet Fakültesi Derg 61: 35-41. https://doi.org/10.1501/vetfak_0000002602 
16. Cary SC, McDonald IR, Barrett JE, Cowan DA (2010) On the rocks: The microbiology of Antarctic dry valley soils. Nat Rev Microbiol 8: 129-138. https://doi.org/10.1038/nrmicro2281

17. CCAMLR, 2004. Protocols for collection of samples for pathological analysis in the event of disease being suspected among monitored species of birds. Part IV. In: CCAMLR ecosystem monitoring programstandard methods. Commission for the Conservation of Antarctic Marine. Cuervo.

18. Cerdà-Cuéllar M, Moré E, Ayats T, Aguilera M, Muñoz-González S, Antilles N, Ryan PG, González-Solís J (2019) Do humans spread zoonotic enteric bacteria in Antarctica? Sci Total Environ 654: 190-196. https://doi.org/10.1016/j.scitotenv.2018.10.272

19. Chen KJ, Chen YP, Chao AN, Wang NK, Wu WC, Lai CC, Chen TL (2017) Prevention of evisceration or enucleation in endogenous bacterial panophthalmitis with no light perception and scleral abscess. PLoS One 12: 1-8.

20. Christensen H, Foster G, Christensen JP, Pennycott T, Olsen JE, Bisgaard M (2003) Phylogenetic analysis by $16 \mathrm{~S}$ rDNA gene sequence comparison of avian taxa of Bisgaard and characterization and description of two new taxa of Pasteurellaceae. J Appl Microbiol 95: 354-363. https://doi.org/10.1046/j.13652672.2003.01986.x

21. Chun J, Oren A, Ventosa A, Christensen H, Arahal DR, da Costa MS, Rooney AP, Yi H, Xu XW, De Meyer S, Trujillo ME (2018) Proposed minimal standards for the use of genome data for the taxonomy of prokaryotes. Int J Syst Evol Microbiol 68: 461-466. https://doi.org/10.1099/ijsem.0.002516

22. Church ML, Priehs DR, Denis H, Croft L, DiRocco S, Davis M (2018) Technique, postoperative complications, and visual outcomes of phacoemulsification cataract surgery in 21 penguins (27 eyes): 2011-2015. Vet Ophthalmol 21: 612-621. https://doi.org/10.1111/vop.12555

23. Claverías FP, Undabarrena A, González M, Seeger M, Cámara B (2015) Culturable diversity and antimicrobial activity of Actinobacteria from marine sediments in Valparaíso bay, Chile. Front Microbiol 6: 737. https://doi.org/10.3389/fmicb.2015.00737

24. CLSI, Clinical and Laboratory Standards Institute, 2018. Performance Standards for Antimicrobial Disk and Dilution Susceptibility Tests for Bacteria Isolated from Animals. 4th ed. CLSI, supplement VET08. Wayne, PA.

25. CLSI, Clinical and Laboratory Standards Institute, 2019. Performance Standards for Antimicrobial Susceptibility Testing; 20th Informational Supplement. CLSI document M100-S19. Replace. M100, 28th ed., Wayne, Pennsylvania, USA. 282.

26. CLSI, Clinical Laboratory and Standards Institute 2018. Interpretive Criteria for Identification of Bacteria and Fungi by Targeted DNA Sequencing, MM18. Wayne, PA: Clinical and Laboratory Standards Institute, MM18, 2nd ed. Replaces MM18-

27. Cole N, Hume E, Khan S, Madigan M, Husband AJ, Garthwaite L, Willcox M (2005) Contribution of the cornea to cytokine levels in the whole eye induced during the early phase of Pseudomonas aeruginosa challenge. Immunol Cell Biol 83: 301-306. https://doi.org/10.1111/j.1440-1711.2005.01324.x

28. Cullen CL (2003) Normal ocular features, conjunctival microflora and intraocular pressure in the Canadian beaver (Castor canadensis). Vet Ophthalmol 6: 279-284. https://doi.org/10.1111/j.14635224.2003.00307.x 
29. Dorella FA, Pacheco LGC, Oliveira SC, Miyoshi A, Azevedo V (2006) Corynebacterium pseudotuberculosis: Microbiology, biochemical properties, pathogenesis and molecular studies of virulence. Vet Res 37: 201218. https://doi.org/10.1051/vetres:2005056

30. Dupont C, Carrier M, Higgins R (1994) Bacterial and fungal flora in healthy eyes of birds of prey. Can Vet J 35: 699-701.

31. Edgar RC (2004) MUSCLE: multiple sequence alignment with high accuracy and high throughput. Nucleic Acids Res 32: 1792-1797. https://doi.org/10.1093/nar/gkh340

32. Fedchenko N, Reifenrath J (2014) Different approaches for interpretation and reporting of immunohistochemistry analysis results in the bone tissue - a review. Diagn Pathol 9;221: 1-12. https://doi.org/10.1186/s13000-014-0221-9

33. Genus Psychrobacter (2020). URL https:///psn.dsmz.de/genus/psychrobacter (accessed 9.3.20).

34. Goloboff PA, Farris JS, Nixon KC (2008) TNT, a free program for phylogenetic analysis. Cladistics 24: 774-786. https://doi.org/10.1111/j.1096-0031.2008.00217.x

35. González-Acuña D, Hernández J, Moreno L, Herrmann B, Palma R, Latorre A, Medina-Vogel G, Kinsella MJ, Martín N, Araya K, Torres I, Fernandez N, Olsen B (2013) Health evaluation of wild gentoo penguins (Pygoscelis papua) in the antarctic peninsula. Polar Biol 36: 1749-1760. https://doi.org/10.1007/s00300013-1394-5

36. Gonzalez-Alonso-Alegre EM, Martinez-Nevado E, Caro-Vadillo A, Rodriguez-Alvaro A (2015) Central corneal thickness and intraocular pressure in captive black-footed penguins (Spheniscus dermersus). Vet Ophthalmol 18: 94-97. https://doi.org/10.1111/vop.12206

37. Griggs A (2019) Ocular Surface Disease in Birds. Vet Clin North Am - Exot Anim Pract 22: 53-68. https://doi.org/10.1016/j.cvex.2018.08.005

38. Gross WB (1957) Escherichia coli Infection of the Chicken Eye. Avian Dis 1: 36. https://doi.org/10.2307/1587544

39. Günther R, Haider W, Hotzel H, Ryll M (2006) Blepharoconjunctivitis in turkeys -the possible role of Bisgaard Taxon 14. 16th Int. Symp. Turkey Dis. 129-133. ISBN3-939902-04-07.

40. ICSP, n.d. (2020) International Committee on Systematics of Prokaryotes. http://www.the-icsp.org/taxacovered-family-pasteurellaceae (accessed 9.3.20).

41. Jara D, Bello-Toledo H, Domínguez M, Cigarroa C, Fernández P, Vergara L, Quezada-Aguiluz M, OpazoCapurro A, Lima CA, González-Rocha G (2020) Antibiotic resistance in bacterial isolates from freshwater samples in Fildes Peninsula, King George Island, Antarctica. Sci Rep 10: 3145. https://doi.org/10.1038/s41598-020-60035-0

42. Jencek JE, Beaufrère H, Tully TN, Garner MM, Dunker FH, Baszler TV (2012) An outbreak of Chlamydophila psittaci in an outdoor colony of Magellanic penguins (Spheniscus magellanicus). J Avian Med Surg 26: 225-231. https://doi.org/10.1647/2010-046R1.1

43. Kaiser P, Stäheli P (2013) Avian Cytokines and Chemokines, in: Schat, KA, Kaspers B, Kaiser PBT-AI (Second E. (Eds.) Avian Immunology: Second Edition. Academic Press, Boston, pp. 189-204. https://doi.org/10.1016/B978-0-12-396965-1.00010-8 
44. Kim M, Chun J (2014) 16S rRNA gene-based identification of bacteria and archaea using the EzTaxon server, in: Methods in Microbiology. Academic Press Inc., pp. 61-74.

https://doi.org/10.1016/bs.mim.2014.08.001

45. Labelle AL, Whittington JK, Breaux CB, Labelle P, Mitchell MA, Zarfoss MK, Schmidt SA, Hamor RE (2012) Clinical utility of a complete diagnostic protocol for the ocular evaluation of free-living raptors. Vet Ophthalmol 15: 5-17. https://doi.org/10.1111/j.1463-5224.2011.00899.x

46. Lee LH, Cheah YK, Sidik SM, Mutalib NSA, Tang YL, Lin HP, Hong K (2012) Molecular characterization of Antarctic actinobacteria and screening for antimicrobial metabolite production. World J Microbiol Biotechnol 28: 2125-2137. https://doi.org/10.1007/s11274-012-1018-1

47. Leigue L, Montiani-Ferreira F, Moore BA (2016) Antimicrobial susceptibility and minimal inhibitory concentration of Pseudomonas aeruginosa isolated from septic ocular surface disease in different animal species. Open Vet J 6: 215-222. https://doi.org/10.4314/ovj.v6i3.9

48. Li HR, Yu Y, Luo W, Zeng YX (2010) Marisediminicola antarctica gen. nov., sp. nov., an actinobacterium isolated from the Antarctic. Int J Syst Evol Microbiol 60: 2535-2539. 2539. https://doi.org/10.1099/ijs.0.018754-0

49. LPSN, (2020) List of Prokaryotic names with Standing in Nomenclature: https://lpsn.dsmz.de/family/pasteurellaceae (accessed 5.9.20).

50. LPSN, (2020). List of Prokaryotic names with Standing in Nomenclature: https://Ipsn.dsmz.de/genus/corynebacterium (accessed 5.9.20).

51. Ludwig W, Klenk HP (2001) Overview: A Phylogenetic Backbone and Taxonomic Framework for Procaryotic Systematics, in: Garrity., D.R.B.R.W.C.\& G.M. (Ed.), Bergey's Manual® of Systematic Bacteriology. Springer, New york, pp. 49-65. https://doi.org/10.1007/978-0-387-21609-6_8

52. Martin GR (1999) Eye structure and foraging in King Penguins Aptenodytes patagonicus. Ibis (Lond. 1859) 141: 444-450. https://doi.org/10.1111/j.1474-919x.1999.tb04413.x

53. Meekins JM, Stuckey JA, Carpenter JW, Armbrust L, Higbie C, Rankin AJ (2015) Ophthalmic diagnostic tests and ocular findings in a flock of captive American flamingos (Phoenicopterus ruber ruber). J Avian Med Surg 29: 95-105. https://doi.org/10.1647/2014-021

54. Meier-Kolthoff JP, Auch AF, Klenk HP, Göker M (2013) Genome sequence-based species delimitation with confidence intervals and improved distance functions. BMC Bioinformatics 14: 60 . https://doi.org/10.1186/1471-2105-14-60

55. Meier-Kolthoff JP, Göker M, Spröer C, Klenk HP (2013) When should a DDH experiment be mandatory in microbial taxonomy? Arch Microbiol 195: 413-418. https://doi.org/10.1007/s00203-013-0888-4

56. Meier-Kolthoff JP, Hahnke RL, Petersen J, Scheuner C, Michael V, Fiebig A, Rohde C, Rohde M, Fartmann B, Goodwin LA, Chertkov O, Reddy T, Pati A, Ivanova N, Markowitz V, Kyrpides NC, Woyke T, Göker M, Klenk HP (2014) Complete genome sequence of DSM 30083T, the type strain (U5/41T) of Escherichia coli, and a proposal for delineating subspecies in microbial taxonomy. Stand Genomic Sci 10; 2: 2014. https://doi.org/10.1186/1944-3277-9-2

57. Michalle Willis A, Wilkie DA (1999) Avian ophthalmology, part 2: Review of ophthalmic diseases. J Avian Med Surg 13: 245-251. https://doi.org/10.2307/30135227 
58. Michalle Willis A, Wilkie DA (1999). Avian ophthalmology part 1: Anatomy, examination, and diagnostic techniques. J Avian Med Surg 13: 160-166. https://doi.org/10.2307/30130679

59. Miller RV, Gammon K, Day MJ (2009) Antibiotic resistance among bacteria isolated from seawater and penguin fecal samples collected near Palmer Station, Antarctica, in: Canadian Journal of Microbiology 55(1):37-45. https://doi.org/10.1139/W08-119

60. Moore BA, Paul-Murphy JR, Adamson KL, Dubielzig RR, Kern T, Gonzales BJ, Wolff P, Murphy CJ (2018) Lipoidal corneal degeneration in aged falcons. Vet Ophthalmol 21: 332-338. https://doi.org/10.1111/vop.12508

61. Nakamura K, Abe F (1987) Ocular lesions in chickens inoculated with Escherichia coli. Can J Vet Res 51: 528-530.

62. Nelson JD, Havener VR, Cameron JD (1983) Impressions of the Ocular Surface. Arch Ophthalmol. 101: 1869-1872.

63. Nesterova AP, Le Bohec C, Beaune D, Pettex E, Le Maho Y, Bonadonna F (2010) Do penguins dare to walk at night? Visual cues influence king penguin colony arrivals and departures. Behav Ecol Sociobiol 64: 1145-1156. https://doi.org/10.1007/s00265-010-0930-3

64. Nievas VF, Leotta GA, Vigo GB (2007) Subcutaneous clostridial infection in Adelie penguins in Hope Bay, Antarctica. Polar Biol 30: 249-252. https://doi.org/10.1007/s00300-006-0179-5

65. Ott L (2018) Adhesion properties of toxigenic corynebacteria. AlMS Microbiol 4: 85-103. https://doi.org/10.3934/microbiol.2018.1.85

66. Park FJ, Jaensch S (2009) Unusual multifocal granulomatous disease caused by actinomycetous bacteria in a nestling Derbyan parrot (Psittacula derbiana). Aust Vet J 87: 63-65. https://doi.org/10.1111/j.1751-0813.2008.00378.x

67. Pasteurellacea, 2020. http://pasteurellacea.eu (accessed 9.3.20).

68. Pattengale ND, Alipour M, Bininda-Emonds ORP, Moret BME, Stamatakis A (2010) How many bootstrap replicates are necessary? J Comput Biol 17: 337-354. https://doi.org/10.1089/cmb.2009.0179

69. Perazzi A, Bonsembiante F, Gelain ME, Patruno M, Di lorio E, Migliorati A, lacopetti I (2017) Cytology of the healthy canine and feline ocular surface: comparison between cytobrush and impression technique. Vet Clin Pathol 46: 164-171. https://doi.org/10.1111/vcp.12450

70. Petznick A, Madigan MC, Garrett Q, Sweeney DF, Evans MDM (2013) Contributions of ocular surface components to matrix-metalloproteinases (MMP)-2 and MMP-9 in feline tears following corneal epithelial wounding. PLoS One 8: 13-18. https://doi.org/10.1371/journal.pone.0071948

71. Pritt B, Mount SL, Cooper K, Blaszyk H (2006) Pseudoactinomycotic radiate granules of the gynaecological tract: Review of a diagnostic pitfall. J Clin Pathol 59: 17-20. https://doi.org/10.1136/jcp.2005.028977

72. Proietto L, Beatty SS, Plummer CE (2019). Comparison of 3 corneal cytology collection methods for evaluating equine ulcerative keratitis: Cytobrush, kimura platinum spatula, and handle edge of scalpel blade. Vet. Ophthalmol. 22: 153-160. https://doi.org/10.1111/vop.12574

73. Qin QL, Xie BB, Zhang XY, Chen XL, Zhou BC, Zhou J, Oren A, Zhang YZ (2014) A proposed genus boundary for the prokaryotes based on genomic insights. J Bacteriol 196(12): 2210-2215. 
https://doi.org/10.1128/JB.01688-14

74. Quinn PJ, Markey BK, Leonard FC, Hartigan P, Fanning S, Fitzpatrick ES (2011) Veterinary microbiology and microbial disease, Second. John Wiley \& Sons, West Sussex, UK

75. Rabbia V, Bello-Toledo H, Jiménez S, Quezada M, Domínguez M, Vergara L, Gómez-Fuentes C, CalistoUlloa N, González-Acuña D, López J, González-Rocha G (2016) Antibiotic resistance in Escherichia coli strains isolated from Antarctic bird feces, water from inside a wastewater treatment plant, and seawater samples collected in the Antarctic Treaty area. Polar Sci 10: 123-131.

https://doi.org/10.1016/j.polar.2016.04.002

76. Sala A, Taddei S, Santospirito D, Sandri C, Magnone W, Cabassi CS (2016) Antibiotic resistance in conjunctival and enteric bacterial flora in raptors housed in a zoological garden. Vet Med Sci 2: 239-245. https://doi.org/10.1002/vms3.38

77. Scott PR, Penny CD (1993) A field study of meningoencephalitis in calves with particular reference to analysis of cerebrospinal fluid. Vet Rec 133: 119-121. https://doi.org/10.1136/vr.133.5.119

78. Sheldon JD, Adkesson MJ, Allender MC, Jankowski G, Langan J, Cardeña M, Cárdenas-Alayza S (2017) Determination of Tear Production and Intraocular Pressure with Rebound Tonometry in Wild Humboldt Penguins (Spheniscus humboldti). J Avian Med Surg 31: 16-23. https://doi.org/10.1647/2015-134

79. Sherman A, Daniels JB, Wilkie DA, Lutz E (2013) Actinomyces bowdenii ulcerative keratitis in a dog. Vet Ophthalmol 16: 386-391. https://doi.org/10.1111/vop.12001

80. Shoshani Y, Pe'er J, Doviner V, Frucht-Pery J, Solomon A (2005) Increased expression of inflammatory cytokines and matrix metalloproteinases in pseudophakic corneal edema. Investig Ophthalmol Vis Sci 46: 1940-1947. https://doi.org/10.1167/iovs.04-1203

81. Shyu LY, Chen KM, Lai SC (2019) Matrix metalloproteinase-2 and matrix metalloproteinase-9 in mice with ocular toxocariasis. Parasitol Res 118: 483-491. https://doi.org/10.1007/s00436-018-06196-4

82. Sila G, Aquino S, Fuller G, Allard S, Woodhouse S (2015) Initial Clinical Experiences with Bilateral Phacoemulsification in Captive Macaroni (Eudyptes chrysolophus) and Southern Rockhopper (Eudyptes chrysocome) Penguins (abstract)., in: 46th Annual Conference of the American College of Veterinary Ophthalmologists.

83. Silvanose CD, Bailey TA, Naldo JL, Howlett JC (2001) Bacterial flora of the conjunctiva and nasal cavity in normal and diseased captive bustards. Avian Dis 45: 447-451. https://doi.org/10.2307/1592986

84. Singh R, Joseph A, Umapathy T, Tint NL, Dua HS (2005) Impression cytology of the ocular surface. Br J Ophthalmol 9: 1655-1659. https://doi.org/10.1136/bjo.2005.073916

85. Stamatakis A (2014) RAxML version 8: a tool for phylogenetic analysis and post-analysis of large phylogenies. Bioinformatics 30: 1312-1313. https://doi.org/10.1093/bioinformatics/btu033

86. Suburo Anglea Maria, Marcantoni M, Scolaro JA (1988) The structure of the eye in Spheniscus magellanicus: dimensions of the cornea and lens in different age groups. colon. Waterbirds 11: 227. https://doi.org/10.2307/1521004

87. Suepaul RB, Alley MR, Van Rensburg MJ (2010) Salt gland adenitis associated with bacteria in blue penguins (Eudyptula minor) from Hauraki Gulf (Auckland, New Zealand). J Wildl Dis 46: 46-54. https://doi.org/10.7589/0090-3558-46.1.46

Page 22/30 
88. Swinger RL, Langan JN, Hamor R (2009) Ocular bacterial flora, tear production, and intraocular pressure in a captive flock of humboldt penguins (Spheniscus Humboldti). J Zoo Wildl Med 40: 430-436. https://doi.org/10.1638/2007-0126.1

89. Swofford DL (2002) PAUP*: Phylogenetic Analysis Using Parsimony (*and Other Methods), Version 4.0 b10. Sinauer Associates, Sunderland.

90. Undabarrena A, Beltrametti F, Claverías FP, González M, Moore ERB, Seeger M, Cámara B (2016) Exploring the diversity and antimicrobial potential of marine actinobacteria from the comau fjord in Northern Patagonia, Chile. Front Microbiol 7: 1135. https://doi.org/10.3389/fmicb.2016.01135

91. Wang HK, Sheng WH, Hung CC, Chen YC, Liew PL, Hsiao CH, Chang SC (2012) Hepatosplenic actinomycosis in an immunocompetent patient. J Formos Med Assoc 111: 228-231. https://doi.org/10.1016/j.jfma.2012.03.001

92. Williams GT, Williams WJ (1983) Granulomatous inflammation - A review. J Clin Pathol 36: 723-733. https://doi.org/10.1136/jcp.36.7.723

93. Wright AM, Mody DR, Anton RC, Schwartz MR (2017) Aberrant staining with Grocott's methenamine silver: utility beyond fungal organisms. J Am Soc Cytopathol 6: 223-227. https://doi.org/10.1016/j.jasc.2017.05.004

94. Xu ZY, Yu Y, Liu Y, Ou CB, Zhang YH, Liu TY, Wang QX, Ma JY (2019) Differential expression of proinflammatory and anti-inflammatory genes of layer chicken bursa after experimental infection with infectious bursal disease virus. Poult Sci 98: 5307-5314. https://doi.org/10.3382/ps/pez312

95. Yoon SH, Ha SM, Kwon S, Lim J, Kim Y, Seo H, Chun J (2017) Introducing EzBioCloud: a taxonomically united database of 16S rRNA gene sequences and whole-genome assemblies. Int J Syst Evol Microbiol 67:1613-1617. https://doi.org/10.1099/ijsem.0.001755

96. Yuan M, Yu Y, Li HR, Dong N, Zhang XH (2014) Phylogenetic diversity and biological activity of actinobacteria isolated from the chukchi shelf marine sediments in the arctic ocean. Mar Drugs 12: 12811297. https://doi.org/10.3390/md12031281

\section{Tables}

Table 1. The phenotypic and physiological characteristics of the isolates 


\begin{tabular}{|c|c|c|c|c|c|c|}
\hline Isolates & TAE3- & TAE3-ERU2 & TAE3- & TAE3- & TAE3-ERU5 & TAE3-ERU6 \\
\hline Characteristics & ERU1 & & & ERU4 & & \\
\hline Gram staining & Negative & Positive & Negative & Positive & Positive & Negative \\
\hline Morphology & Coccobacilli & $\begin{array}{l}\text { Bacilli and } \\
\text { coryneform }\end{array}$ & Bacilli & Bacilli & $\begin{array}{l}\text { Cocobacilli } \\
\text { and bacilli }\end{array}$ & $\begin{array}{l}\text { Cocobacilli } \\
\text { and bacilli }\end{array}$ \\
\hline Motility & - & - & - & - & - & - \\
\hline \multicolumn{7}{|c|}{ Growth in $\mathrm{NaCl}(w / v)$} \\
\hline 0 & + & + & - & - & + & - \\
\hline $2 \%$ & + & + & + & + & + & + \\
\hline $5 \%$ & + & + & + & + & + & + \\
\hline $10 \%$ & - & + & + & - & - & - \\
\hline \multicolumn{7}{|l|}{ Growth at } \\
\hline $4{ }^{\circ} \mathrm{C}$ & + & $+*$ & + & $+^{*}$ & $t^{*}$ & + \\
\hline $22^{\circ} \mathrm{C}$ & + & + & + & + & + & + \\
\hline \multicolumn{7}{|l|}{$37^{\circ} \mathrm{C}$} \\
\hline Aerobic & + & + & + & + & + & + \\
\hline Microaerobic & + & + & + & + & + & + \\
\hline Anaerob & + & + & - & + & + & - \\
\hline $\begin{array}{l}\text { Mac Conkey } \\
\text { agar }\end{array}$ & + & - & - & - & - & - \\
\hline $42^{\circ} \mathrm{C}$ & + & + & - & + & + & $+*$ \\
\hline \multicolumn{7}{|l|}{ Activity of } \\
\hline Urease & - & - & - & - & - & + \\
\hline Oxidase & - & - & + & - & - & + \\
\hline Catalase & + & + & + & + & + & + \\
\hline Esculin & $+v$ & - & - & - & - & - \\
\hline \multicolumn{7}{|c|}{ Utilization of specifis sugars } \\
\hline Mannitol & - & - & - & - & - & - \\
\hline Xylose & - & - & - & - & + & - \\
\hline
\end{tabular}




\begin{tabular}{|lcccccc|} 
Arabitol & - & - & - & - & - & - \\
Ribose & - & - & - & - & - & - \\
Rhamnose & - & - & - & - & - & - \\
\hline Trehalose & - & - & - & - & - & - \\
\hline Tagatose & - & - & - & - & - & - \\
\hline
\end{tabular}

*: weakly, v: variable

Table 2. Information on the GenBank-registered bacteria, to which the 16S rRNA gene sequence results of the isolates showed similarity, and the rates of similarity

\begin{tabular}{|c|c|c|c|c|c|c|}
\hline \multirow[t]{2}{*}{ Isolates } & \multirow{2}{*}{$\begin{array}{l}\text { Accession } \\
\text { Number }\end{array}$} & \multicolumn{2}{|l|}{ BLAST results } & \multicolumn{2}{|l|}{ EZBio Cloud } & \multirow{2}{*}{$\begin{array}{l}\text { GenBank } \\
\text { informations of the } \\
\text { isolates in this } \\
\text { study }\end{array}$} \\
\hline & & $\begin{array}{l}\text { Species } \\
\text { matched }\end{array}$ & $\begin{array}{l}\text { Per. } \\
\text { ident }\end{array}$ & $\begin{array}{l}\text { Species } \\
\text { matched }\end{array}$ & $\begin{array}{l}\text { Per. } \\
\text { ident }\end{array}$ & \\
\hline $\begin{array}{l}\text { TAE3- } \\
\text { ERU1 }\end{array}$ & MT444110.1 & $\begin{array}{l}\text { Bisgaard taxon } \\
14 \text { strain }\end{array}$ & 98.65 & $\begin{array}{l}\text { Pasteurella } \\
\text { testudinis }\end{array}$ & 94.22 & $\begin{array}{l}\text { Pasteurellaceae } \\
\text { bacterium }\end{array}$ \\
\hline $\begin{array}{l}\text { TAE3- } \\
\text { ERU2 }\end{array}$ & MT444111.1 & $\begin{array}{l}\text { Corynebacterium } \\
\text { ciconiae }\end{array}$ & 98.76 & $\begin{array}{l}\text { Corynebacterium } \\
\text { ciconiae }\end{array}$ & 99.05 & $\begin{array}{l}\text { Corynebacterium } \\
\text { ciconiae }\end{array}$ \\
\hline \multirow[t]{2}{*}{$\begin{array}{l}\text { TAE3- } \\
\text { ERU3 }\end{array}$} & \multirow[t]{2}{*}{ MT444112.1 } & \multirow{2}{*}{$\begin{array}{l}\text { Cardiobacterium } \\
\text { sp. feline oral } \\
\text { taxon }\end{array}$} & \multirow[t]{2}{*}{94.70} & $\begin{array}{l}\text { Pasteurella } \\
\text { testudines }\end{array}$ & 94.22 & \multirow[t]{2}{*}{$\begin{array}{l}\text { Cardiobacteriaceae } \\
\text { bacterium, }\end{array}$} \\
\hline & & & & Rappaport israeli & 93.92 & \\
\hline $\begin{array}{l}\text { TAE3- } \\
\text { ERU4 }\end{array}$ & MT444113.1 & $\begin{array}{l}\text { Actinomyces } \\
\text { liubingyangii }\end{array}$ & 97.19 & $\begin{array}{l}\text { Actinomyces } \\
\text { liubingyangii }\end{array}$ & 97.40 & Actinomyces sp. \\
\hline $\begin{array}{l}\text { TAE3- } \\
\text { ERU5 }\end{array}$ & MT444114.1 & $\begin{array}{l}\text { Devriesea } \\
\text { agamarum }\end{array}$ & 97.14 & $\begin{array}{l}\text { Devriesea } \\
\text { agamarum }\end{array}$ & 96.88 & $\begin{array}{l}\text { Dermabacteraceae } \\
\text { bacterium }\end{array}$ \\
\hline $\begin{array}{l}\text { TAE3- } \\
\text { ERU6 }\end{array}$ & MT674807.1 & $\begin{array}{l}\text { Psychrobacter } \\
\text { pygoscelis }\end{array}$ & 99.03 & $\begin{array}{l}\text { Psychrobacter } \\
\text { pygoscelis }\end{array}$ & 99.11 & $\begin{array}{l}\text { Psychrobacter } \\
\text { pygoscelis }\end{array}$ \\
\hline
\end{tabular}

\section{Figures}



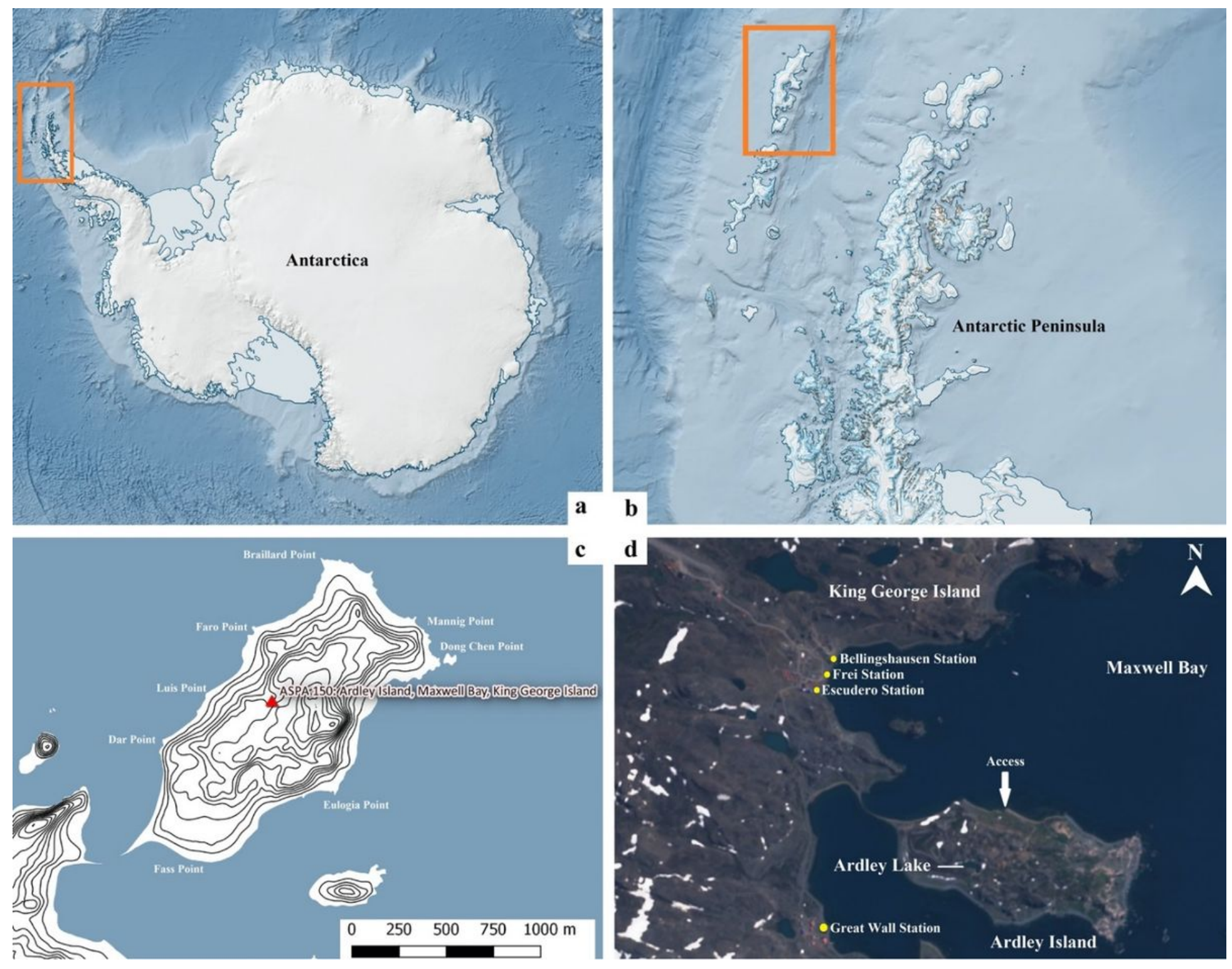

Figure 1

The region in ASPA 150 Ardley Island, where the ocular samples were taken from a Gentoo penguin (a-d). The orange box shows the continental position of the Antarctic Peninsula (a). The orange box shows the location of King George Island (b). The red arrowhead indicates the material collection site on Ardley Island; scale bar $1000 \mathrm{~m}$ (c). The research access area and nearby stations are seen in the satellite image (d). Note: The designations employed and the presentation of the material on this map do not imply the expression of any opinion whatsoever on the part of Research Square concerning the legal status of any country, territory, city or area or of its authorities, or concerning the delimitation of its frontiers or boundaries. This map has been provided by the authors. 

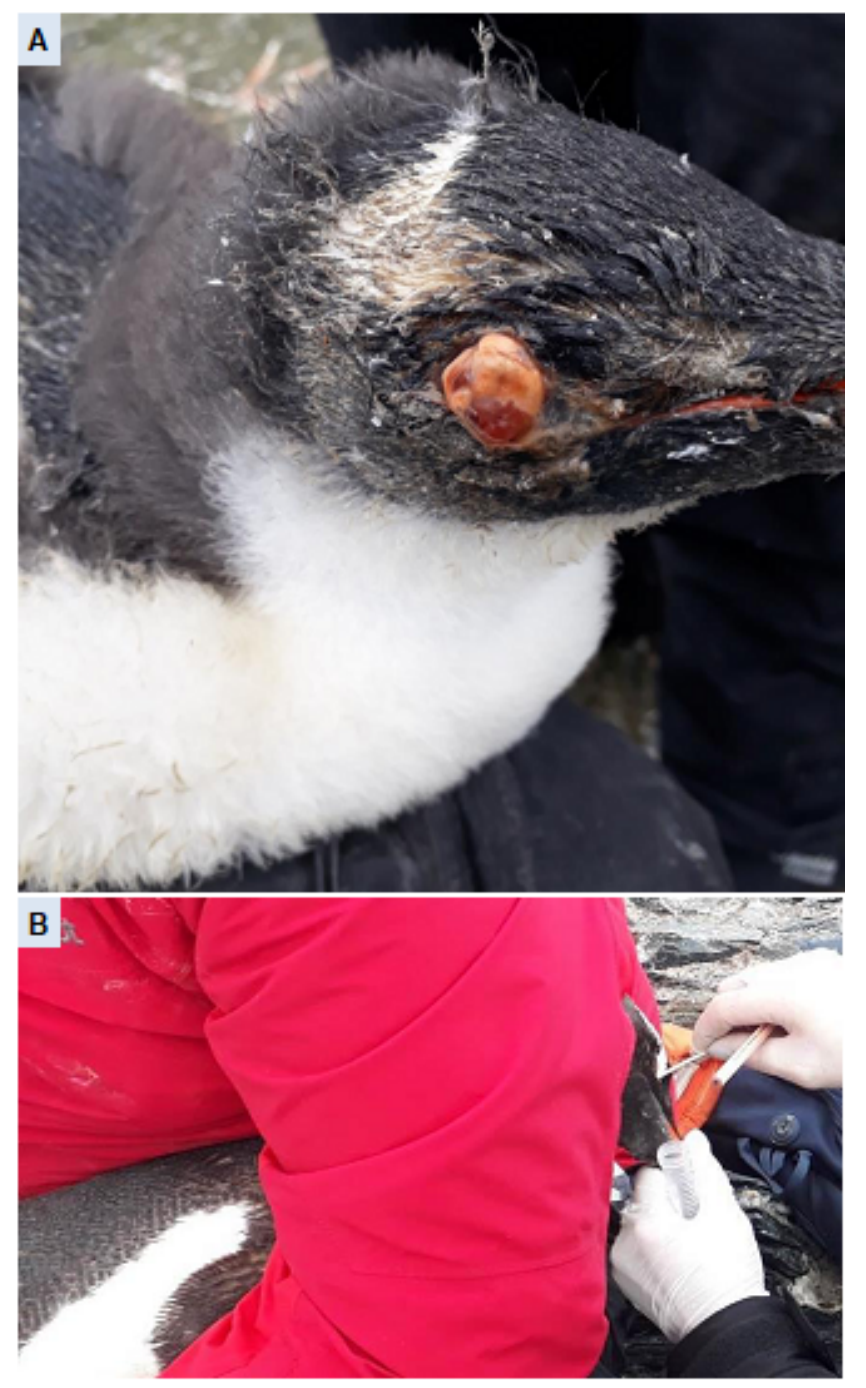

Figure 2

Evaluation of eye lesion on Gentoo penguin (Pygoscelis papua) chick A) The right eye of a Gentoo penguin chick. A reddish-orange exophytic tissue obscured the view of the cornea. B) The corneal surface of the Gentoo penguin was sampled for bacterial culture. 


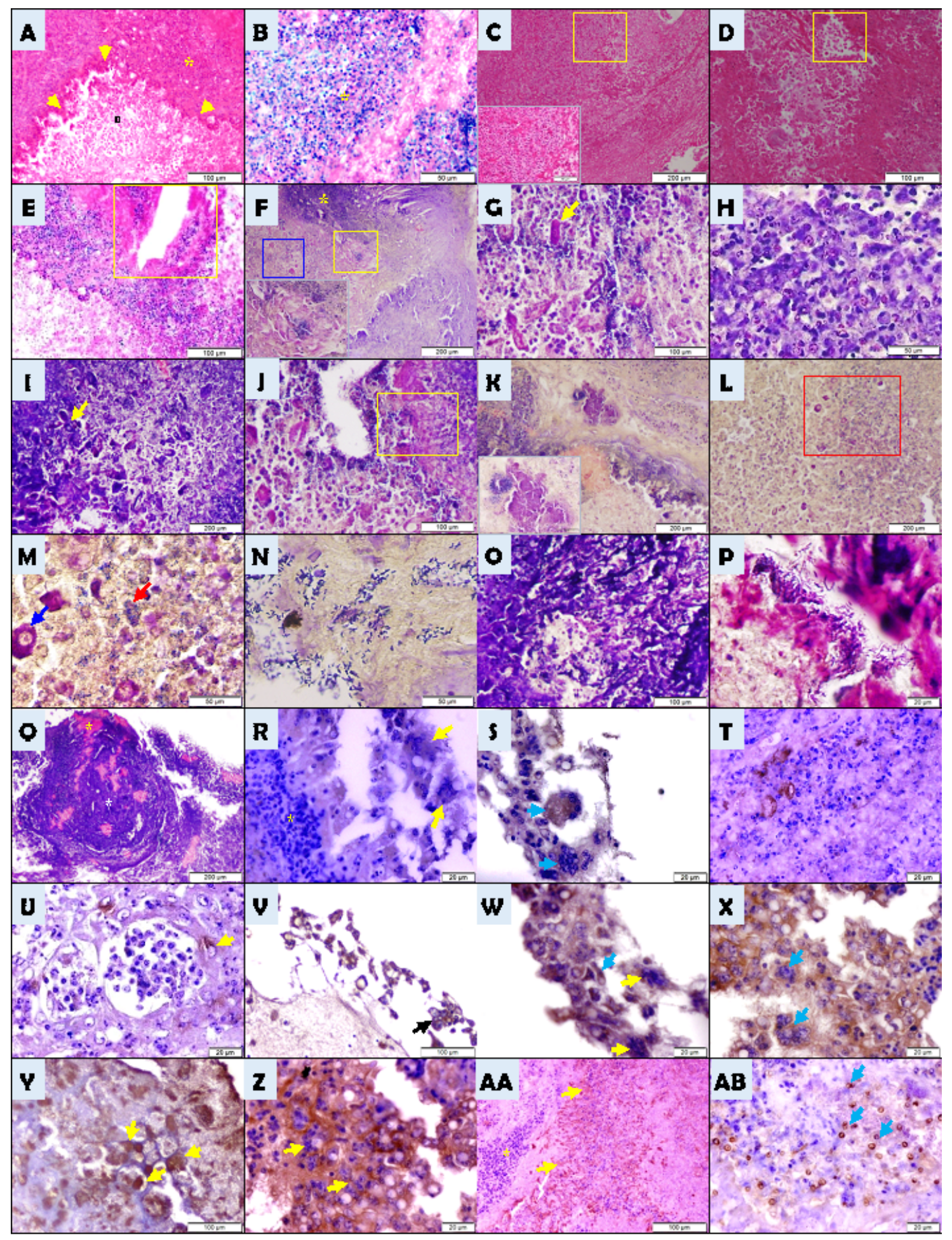

\section{Figure 3}

Histopathology of the exophytic tissue in the right eye of the penguin ( $A-A B) A$ ) Pyogranuloma in the anterior chamber of the eye, including the cornea and iris: Necrosis (n), infiltration of numerous macrophages and heterophils, and fewer lymphocytes $\left(^{*}\right)$ characterized by giant cells surrounding the central necrotic region (arrowheads). B) Numerous infiltrating cells consisting mainly of mononuclear cells, imaged at a higher magnification as shown by a star (*) in Fig. A. C) Fibrin, bacteria, and necrotic inflammatory cells (yellow boxed area) and haemorrhage. Inset: Higher magnification view of the yellow boxed area. D) Higher 
magnification view of the necrotic area (n) in Figure (A). Necrotic debris and distended macrophages containing bacteria (yellow boxed area). E) Pyogranulomatous nodule surrounded by infiltrates of lymphocytes and plasma cells. Infiltration of the necrotic area with heterophils and macrophages containing numerous bacteria (boxed area). F) Brown-Brenn staining of Figure (A). Severe pyogranulomatous inflammation with inflammatory cell infiltration composed of lymphocytes, plasma cells, and histiocytes (*). Macrophages with bizarre nuclei (dark blue boxed area). An abundance of Gram-positive bacteria in and around an area of necrosis (yellow boxed area, Inset: Higher magnification of the yellow boxed area). The image shows Gram-positive bacteria of different morphology, observed as many intracellular and extracellular clumps within the exudate. G) Higher magnification of the dark blue boxed area in Figure (F). An abundance of Gram-positive bacteria found in and around an area of necrosis and macrophages with bizarre nuclei (arrow). H) Higher magnification of the star $\left(^{\star}\right)$ in Fig. B. Corneal epithelium infiltrated with reactive macrophages and lymphocytes. I) Higher magnification of the star (*) in Figure F. Macrophages with bizarre nuclei (arrow), and many degenerate neutrophils and multinucleated giant cells with several cocci within their cytoplasm. J) Brown-Brenn staining of Fig. 1E. Ocular manifestations of the anterior segment. Dense mononuclear infiltration. Necrotic cell debris with multiple Gram-positive and Gram-negative bacteria (boxed area). K) An abundance of Gram-positive and Gram-negative bacteria within and around an area of necrosis. Inset: Higher magnification. L) Pyogranulamatous inflammation composed mainly of reactive macrophages (bizarre cells) (red boxed area), heterophils, and fewer lymphocytes. M) Higher magnification of the red boxed area in Figure L. Gram-positive (red arrow) and Gram-negative bacteria (blue arrow) in the cytoplasm of macrophages. N) Numerous Gram-positive bacilli in the area of necrosis. 0) Higher magnification of the Brown-Brenn staining of the yellow boxed area in Figure D. Typical granuloma. Numerous bacteria of different morphology in the parenchyma of the anterior camera. Filamentous and branching Gram-positive bacteria. P) Higher magnification of the yellow boxed area in Fig. J. Gram-positive and Gram-negative cocci, coccobacilli and filamentous bacilli. Q) Multiple granulomas with central necrosis (one is indicated by a yellow star). Granulomatous inflammation consisting of macrophages, lymphocytes, and fewer heterophils (one is indicated by a white star). R-X) Immunohistochemical staining of pro-inflammatory cytokines in the conjunctival epithelium of the right eye with panophthalmitis. $R, S$ ) Demonstration of IL- $1 \beta$ by IHC staining in the granuloma cells. R) IHC staining of Figure A. Langhans giant cells with positive immunoreactivity (one is indicated by a yellow arrow), and many lymphocytes, macrophages and epithelioid cells with negative

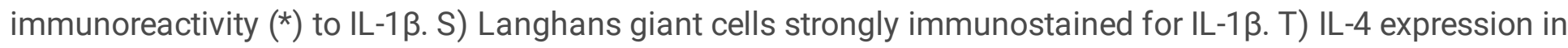
the granuloma cells. U-V) Macrophages with positive immunoreactivity for IL-6 (shown by yellow and black arrows). W) Langhans giant cells (yellow arrows) and conjunctival goblet cells (one is shown by the blue arrow) with positive immunoreactivity for IL-6. Y, Z) MMP-9 expression in the corneal epithelium (yellow arrows). X) Blue arrows indicate stromal keratocytes with strong MMP-9 expression. AA-AB) Strong immunoreactivity of the choroid and sclera for TNF-a. Bars of main plate: $20 \mu \mathrm{m}(\mathrm{P}, \mathrm{R}-\mathrm{U}, \mathrm{W}, \mathrm{X}, \mathrm{Z}, \mathrm{AB}), 50 \mu \mathrm{m}$ (B, $H, M, N), 100 \mu m(A, D, E, G, J, O, V, Y, A A)$, and $200 \mu m(C, F, I, K, L, Q)$. Bars of insets: $50 \mu \mathrm{m}(C, K), 100 \mu \mathrm{m}(\mathrm{F})$. Stains of main plate: Haematoxylin and eosin (A-E), Brown-Brenn Gram (F-Q), immunoperoxidase-3,39diaminobenzidine (DAB chromogen and counterstained with haematoxylin) (R-AB). Stains of insets: Haematoxylin and eosin (C) and Brown-Brenn Gram (F, K). 


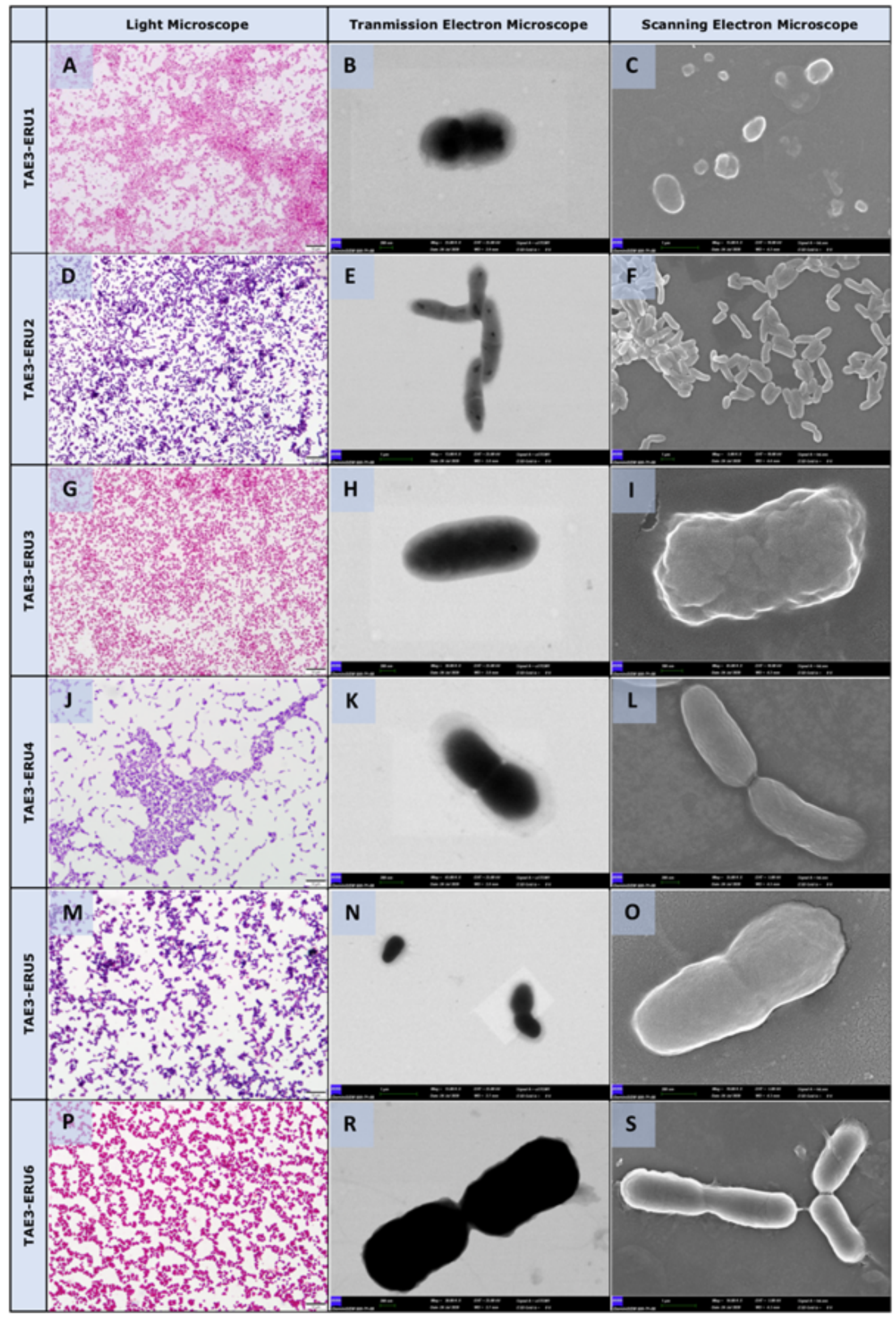

\section{Figure 4}

Morphological analysis of the bacterial isolates by light microscope (panels on the left-hand side, Gram staining) Transmission electron microscope (panels on the middle) and Scanning electron microscopy SEM (panels on the right-hand side) Standard cell morphology of TAE3- ERU1 (Pasteurellaceae bacterium, A-C), TAE3- ERU2 (Corynebacterium ciconiae, D-F), TAE3- ERU3 (Cardiobacteriaceae bacterium, G-I), TAE3- ERU4 (Actinomyces sp., J-L), TAE3- ERU5 (Dermabacteraceae bacterium, M-O) and TAE3- ERU6 (Psychrobacter pygoscelis, P-S) Bar: $10 \mu \mathrm{m}(\mathrm{A}, \mathrm{D}, \mathrm{G}, \mathrm{J}, \mathrm{M}, \mathrm{P}), 1 \mu \mathrm{m}$ (E,C,F,S), $100 \mathrm{~nm}(\mathrm{I}), 200 \mathrm{~nm}(\mathrm{~B}, \mathrm{H}, \mathrm{K}, \mathrm{L}, \mathrm{R}, \mathrm{O})$ 